University of Louisville

ThinkIR: The University of Louisville's Institutional Repository

Electronic Theses and Dissertations

$5-2012$

\title{
The incredible tale of Johanna, the blessed listener.
}

Jared Andrew Beek 1986-

University of Louisville

Follow this and additional works at: https://ir.library.louisville.edu/etd

\section{Recommended Citation}

Beek, Jared Andrew 1986-, "The incredible tale of Johanna, the blessed listener." (2012). Electronic Theses and Dissertations. Paper 93.

https://doi.org/10.18297/etd/93

This Master's Thesis is brought to you for free and open access by ThinkIR: The University of Louisville's Institutional Repository. It has been accepted for inclusion in Electronic Theses and Dissertations by an authorized administrator of ThinkIR: The University of Louisville's Institutional Repository. This title appears here courtesy of the author, who has retained all other copyrights. For more information, please contact thinkir@louisville.edu. 


\title{
THE INCREDIBLE TALE OF JOHANNA, THE BLESSED LISTENER
}

\author{
By \\ Jared Andrew Beek \\ B.A., University of Kentucky, 2009 \\ A Creative Thesis \\ Submitted to the Faculty of the \\ College of Arts and Sciences of the Unviersity of Louisville \\ in Partial Fulfillment of the Requirements \\ for the Degree of
}

Master of Arts

Department of English

University of Louisville

Louisville, Kentucky

May 2012 


\section{Copyright 2012 byJared Andrew Beek}

All rights reserved 
THE INCREDIBLE TALE OF JOHANNA, THE BLESSED LISTENER

By

Jared Andrew Beek

B.A., University of Kentucky, 2009

A Thesis Approved on

April 23, 2012

by the Following Thesis Committee:

Paul Griner, Thesis Director

Courteney M. Petrosino

Rhonda L. Buchanan 


\section{ABSTRACT \\ THE INCREDIBLE TALE OF JOHANNA, THE BLESSED LISTENER \\ Jared Andrew Beek}

April 23, 2012

In this novella, a young girl wakes to discover she has lost her voice and that people can no longer hold their secrets back from her. Tasked with offering them absolution through listening, she must also deal with the increasing toll bearing these secrets places on her. An exploration of the difficulties that emerge in navigating social relationships and difficult situations on the cusp of adulthood, this novella seeks to incorporate elements of magical realism and fairy tale to create afantastical bildungsroman that also pays homage to the work of Gabriel García Márquez. 
TABLE OF CONTENTS

\section{PAGE}

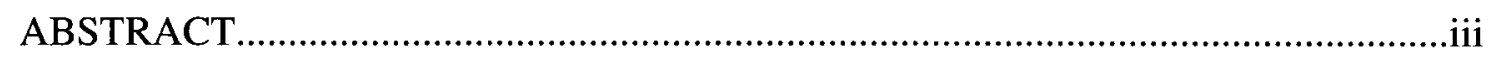

I

II.

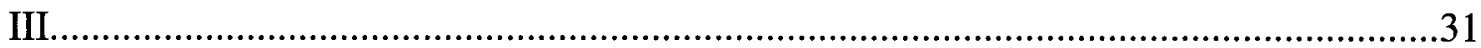

IV

$\mathrm{V}$

CURRICULUM VITAE 
The afternoon sun glared down, sending rivers of sweat down Johanna's back as she worked in her mother's garden. She surveyed the tomatoes, gently plucking one from its stem. It detached with a soft snap, and she rolled it around in her fingers. Its fever red skin was warm to the touch, but still firm. A shadow fell over Johanna, and her mother's hand snatched the tomato from her. Her mother examined it delicately, her long fingers pressing just ever so slightly on the skin. While she looked it over, she absentmindedly reached for Johanna, resting her other hand on the side of Johanna's head, an awkward sign of affection that felt more like an afterthought. Finally, she smiled, seemingly satisfied, and slipped the tomato into a plastic bag. "Seems like we've got some real beauties this summer," she said, not quite talking to Johanna, before shoving past her to look more closely at one of the vines.

"Damn beetles have been at them again," she muttered and began to coo softly to the plants. "Oh, what have those little bastards done to you?"

Johanna stoodup quietly, stepping back out of her mother's way.Shielding her eyes, she looked around the garden. The peppers were also beginning to look healthy, and the small section of watermelon, the one part of the garden her mother had let her choose for her own, had yielded some modestly sized, plump green fruit. Beyond the tall poles where the tomatoes grew, Johanna could make out a shape moving slowly down the dirt 
road that ran behind the row of houses. From the profile and the slow, careful gait of the person, Johanna knew it must be the Widow Sánchez. The widow was the source of many childhood tales of horror in her neighborhood, with vague stories of children entering her house and never being seen again. They called her a witch. And, most frighteningly to many young children, she had no eyes, though she often covered up her face with dark glasses.

The cause of her blindness was the source of much speculation. Many said she had found a way to go back in time. Some ancient and powerful spell that she had discovered wandering forgotten caves in a desert. When she had cast the spell, she had wanted to go to the beginning, to see the Earth in its forming. But she found herself in a primordial sea; asteroids went streaking through the sky above her, while others came crashing down into the ocean, their brilliant white tails sizzling into the water. She couldn't breathe in the lack of atmosphere. And some said that when she looked up, her eyes were burned out by the new sun, ablaze with a cosmic fury that could make the oceans boil. Others said that she had looked upon the face of God as he brought the planet together, that her eyes were destroyed as she, for just a moment, saw the Creator forming Eden. Without her sight, she could not cast the spell to return, and was doomed to walk the earth for eons, a creature out of time. At some point, every kid would claim that their great-grandparents had known the widow, and that she had been ancient even then. No one even knew why she was called a widow; no husband had ever been seen or heard of. 
Johanna had never spoken to her, but she didn't find her terrifying. Instead, the widow had always seemed serene but lonely. Johanna watched as she passed, and wondered where she was off to on a hot day like today.

"Johanna!" her mother shouted, snapping her from her thoughts.

"Yes, mother?"

"Take these in and put them in a cool place. We'll use them for dinner."

"Yes, ma'am," Johanna said, accepting the plastic bag of vegetables and then turning back to the house. Before she went inside, however, she stole one more glance out into the dirt road, but the widow had disappeared.

After dinner that night, Johanna went to her room and sat at her desk contemplating the widow. Johanna often wondered about her neighbors, thinking about their lives before they had moved to this quiet neighborhood. It was a little game for her, inventing stories about them when her mother needed her to be out of the way while she read or cooked or just wanted Johanna to be elsewhere. The widow, however, was a source of mystery. Johanna knew some things about her neighbors. There was the seamstress, the sea captain, the chef, and more that surrounded her, but the widow was something else entirely.

Johanna opened up the window to let some of the night air in. She listened to the sound of the crickets outside, whose chirping over the summer had gradually become more grandiose, sounding something more like Beethoven than the more unmelodic sound of their usual songs. They were getting ambitious in the heat. Still thinking about the widow and imagining the lush, green paradise of Eden, Johanna lay down on her bed. 
Before long, she had drifted off to sleep, where she dreamed she was with the widow, afloat in a dark and raging sea. Far ahead of them, a giant volcano erupted as lightning danced around the center of its rage, sending electric jolts into the plumes of lava.

"It's beautiful, isn't it?" the widow asked her, but a harsh wind was blowing and it ripped Johanna's answer from her lips, whipping it away to the darkness in the back of her mind.

In the waking world, a wind blew in through the curtains, ruffling papers on Johanna's desk, flowingalong the wall before it finally reached Johanna's sleeping form. A small gasp escaped her throat, and the wind carried it off as it retreated, streaming back out through the open window, barely moving the curtains on the way out. The room settled and only silence remained.

\section{\#}

In the morning, Johanna woke up to her mother's pounding on the door.

"Breakfast!" her mother yelled, and then Johanna could hear her footsteps moving back down the hallway. Johanna stretched her arms out and yawned, not noticing at first that no sound came from her mouth. It was only when she tried to hum to herself that she perceived the curious silence. She opened her mouth and tried to utter a cheerful, "Hello!" Nothing. Was she sick? She held her hand to her forehead. There didn't seem to be a fever. Johanna left her room and went to the bathroom, loudly shutting the door so her mother wouldn't yell up the stairs to see why she wasn't out of bed yet.

She checked herself in the mirror. She was deeply tanned from the work in the garden, but still looked healthy, and no feverish blush appeared in her cheeks. Her green eyes looked normal. She opened her mouth wide and looked at her tonsils. They were a 
healthy, fleshy pink. She tried to yell, but only a whoosh of breath came out and fogged up the mirror. She ran through a mental checklist of all the things that could have possibly resulted in her being stricken dumb, but couldn't think of any reason outside of sickness or some strange act of God. Hoping for the former, she decided to see if she could get her mother to call a doctor. Maybe it was just a passing sickness, but she needed to know.

When she entered the kitchen, her mother barely glanced up from reading the newspaper. "Food's getting cold," her mother said, thrusting a plate of scrambled eggs with tomatoes, peppers and onions at her without looking. Joanna quickly steadied the plate to keep the food from tumbling to the floor, and then carefully set it down on the table. She turned to her mother and opened her mouth to tell her that she thought something was wrong with her throat, but then, of course, realized that she would not be able to get the words out. Instead, she looked around the kitchen for something to write on.

“What are you doing?" her mother asked. Johanna held up a finger and rummaged through the junk drawer to find a pen. Noticing a receipt still lying on the counter, she snatched it up and turned it over. Something is wrong with my voice. I think I'm sick.

"What do you mean something is wrong with your voice?" Johanna shook her head and shrugged, pointing to her mouth. Her mother gave a huff. "Come here." She gripped Johanna's face tightly in her fingers, peering into her throat. She gave a cluck and released Johanna.

"Your throat looks just fine. I don't know what you are talking about." 
Johanna tried to indicate that she wasn't in fact talking about anything because she couldn't, but she just shook her head and wrote down that she wanted to see a doctor. Her mother ignored her frantic gestures and continued.

“This is so like you. I never would've gotten away with this when I was your age. You know what your grandmother said to me once? I broke one dish and she looked me in the eye and said, 'I should've eaten you while your bones were soft.' My father thought it was the funniest thing he'd ever heard. She was terrifying when she was angry. I hated that woman, but I wish she were here right now. She never would've tolerated a child like you."

Johanna stopped her gesticulations, mouth open. Her mother had never spoken to her this way, and sheso rarely talked about her parents. She seemed just as surprised as Johanna that the topic had come up. A strange look came over her face, relief mixed with slight embarrassment. She stared hard at Johanna, the look of discomfort growing.

"I don't know why you feel like you need all of this attention," she spat. She got up and pointed at the plate of eggs. "You'd better eat. I'll call Dr. Ratliff and see if he can come by later this afternoon," she said, and walked out of the kitchen.

Johanna watched her leave, feeling guilty despite the fact that she was not sure what had just happened. She sat down at the head of the table, absentmindedly pushing the cold breakfast from one side of the plate to the other as she stared out the back window. It was a beautiful day outside. She dumped her breakfast into the trash and went to her room. 
Johanna had just drifted off into a half-conscious state when she heard a knock on the door.

"Johanna! Dr. Ratliff is here!" her mother called before opening the door. Dr. Ratliff ambled into the room with his large black bag, smiling jovially. He was a large man, prone to wearing Hawaiian shirts and khakis year-round, but he was always kind and did many house calls for children in the neighborhood. But as a pediatrician, he always seemed to be stuck in the frame of mind that Johanna was seven, not fifteen.

"Well, Johanna, your mother tells me that it appears a cat has got your tongue," Dr. Ratliff said as he moved her desk chair, placing it down in front of her bed. He plopped down with a sigh, his ample sides spilling over the edge of the chair. It creaked in protest, but held steady. "If you don't mind, I'd like to take your temperature and then have a look-see at your throat." Johanna sat up in bed and opened her mouth, lifting her tongue so he could tuck the thermometer in between her tongue and her teeth, and then she waited as he allowed it to measure what she already knew would be a normal body temperature.

“School's just around the corner, isn't it? You'll be in high school before you know it!"

If she'd had a voice, she would have replied that she'd been in high school for two years, though it would have been muffled by the thermometer. Instead, she just nodded and continued waiting. Finally, he took it out and then diagnosed her temperature as perfectly healthy. He tucked the thermometer down into a small plastic container and then dug out a tongue depressor and a small flashlight from deep in the bag. He ripped open the wrapper of the tongue depressor, rolled it up and launched it at the small trash 
can by her desk. It missed by several feet, floating limply to land in the center of the room.

“All right, then, let's see that throat. Say 'Ah!' Well, I suppose you can't, but try anyway." Johanna opened her mouth wide, tasting the bland wood of the depressor as Dr. Ratliff squinted in concentration at the back of her throat.

"Hmm, curious," he muttered to himself. "Your throat looks fine, too." He stopped and considered her for a few moments. "Well, Johanna, it seems that you are perfectly physically healthy. And yet you have no voice." He looked around to see if her mother was hovering in the doorway, but she had long since wandered off to another part of the house.

“Is everything okay here? If you're just pretending, don't worry. We're old pals. I can keep a secret." Johanna didn't know whether to shake her head or nod. She chose shrugging instead.

"You know, I know that it can be tough sometimes. My dad was no picnic to be around all of the time. When I was six, he caught me playing dolls with my sisters, and he told me he would buy me a dress to wear with them to Sunday school. I started crying, and he grabbed me by the ear and took me outside. There were thistles that ran along a ditch line on the back of our property, and he made me run back and forth through them for an hour, just watching me, yelling whenever I tried to stop. Finally, when I came crawling through one last time, on the verge of passing out, he let me stop. I couldn't walk, and my body was covered in scratches. My clothes had rips and tears, and I was bleeding all over the place. I was in tears, and collapsed on the ground. He said that now I could cry. My blood was the mark of a man. He never hit me or my sisters, but I have 
never hated someone so much as that man. I chose to work with children because of him, because I wanted to see kids treated with kindness and care. I...” Dr. Ratliff looked up. His flushed face turned a deeper shade of crimson.

'I'm sorry, Johanna. I don't know what's gotten into me. You're much too young to be hearing all of that." He shifted uncomfortably in the chair, and it groaned once again. Johanna, unsure of what to do, reached out her hand and placed it on his thick forearm. He looked up at her and gave a crooked smile. Awkwardly, he leaned forward and wrapped her in his arms. Johanna returned the hug, resting her hands on a sweaty patch on his back. Johanna's mother appeared in her doorway and cleared her throat. Dr. Ratliff jumped, nearly sending the chair tumbling backward.

"What in the hell is going on, Doctor?" she asked. Dr. Ratliff's face grew even more impossibly red.

"Nothing," he said, staring down at the floor.

"I didn't ask you here to be her father; I asked you to check and see why she is acting like she can't speak. Is she sick or not?"

"Well, Bev, it seems that she might just need a little rest for a few days. Maybe with some hot tea with lemon and a littlesoup. She'll be fine; it's nothing serious." He looked over at Johanna and winked.

"Is she contagious?"

"No, no. It's really not much of anything."

Johanna's mother crossed her arms and stared down at Dr. Ratliff, who once again shifted uncomfortably in his chair. 
"Well, I really must be going. Have to get back across town for another appointment. Remember, just let her rest and she should be fine," he said and stood up from the chair.

"I'll show you out," her mother said, casting a suspicious look at Johanna as she stepped aside to let him pass through the doorway. Johanna heard some polite chatter as they moved down the steps, and the front door closed shortly after. Johanna heard her mother immediately go to the phone, and there was a hushed conversation in the foyer. She went to the edge of her room to try and hear what her mother was saying, but she couldn't make out a word. Her mother hung up and then moved to the kitchen, where there was the sound of objects being moved as she rifled through some drawers, and then aloud tearing noise. Johanna returned to her room when she heard her mother start to head back to the stairs.

When she appeared in the doorway, Johanna saw that she had taped her mouth shut. She had a notepad in a pen in hand.

I don't know what's wrong with you, but I've called for a second opinion. He'll be here later this afternoon. Until then, you are not to leave this room. Johanna didn't acknowledge that she had read the message. Her mother huffed and shut the door.

When the doorbell rang, Johanna sat up in bed, wondering what doctor she was to see now. She had never seen anyone but Dr. Ratliff for as long as she could remember. When they opened her door, Johanna saw that her mother had not called another doctor, but had called a priest. 
He was a small man, and the black suit made him look even smaller. Johanna guessed that he was around forty; his hair was speckled with grey and he had prominent wrinkles on his face, especially his laugh lines. Johanna immediately felt like she could trust him. He smiled as he came closer and took a seat on the chair that Dr. Ratliff had used only a couple of hours before.

“Hello, Johanna, I'm Father O'Brien,” he said, his voice deep and slightly husky. He nodded to her mother, who backed out of the room and shut the door.

"Your mother tells me that you seem to have been stricken with silence and yet you seem perfectly healthy," he said. He smiled a bit. "I tried to tell her that it is not in the interest of the church to investigate such cases without more evidence of miraculous events, but she said that something strange was happening. I'm not here officially, nor will I exorcise you, so you can relax. The holy water will be kept safely stored. I just wanted to talk. Would that be okay?"

Johanna nodded.

“Good. So, I'm not sure if you are familiar with the story of St. Zachary, the father of John the Baptist. It is my understanding that, despite your mother's upbringing, you do not attend mass regularly. Tell me, do you know what happened to St. Zachary?" Johanna shook her head.

“Oh, it's a very interesting story. He was a priest, and one day, while performing his duty and making his offering at the altar of incense, the angel Gabriel appeared to him and said that his wife, Elizabeth, despite her age and barrenness, would bear a son and that his name would be John. St. Zachary asked for a sign to verify this prophecy, not believing the angel, and so he was struck dumb, unable to speak. 
"When he returned home to Hebron, Elizabeth—who was Mary's cousin, you know-did become pregnant, and she eventually gave birth to a son. All of their neighbors thought his parents would name him Zechariah, after his father, but, instead, Elizabeth said she would name him John. And they thought, 'Well, this is odd. None of their relatives have the name John,' and so they asked St. Zachary what he would name the son. After getting a writing tablet, St. Zachary wrote, 'His name is John.' Immediately, his mouth was opened and he regained his ability to speak, and so he blessed the Lord, God of Israel, and gave the Benedictus, a song of thanksgiving."

Father O'Brien paused, letting Johanna absorb the story. She pointed toward the papers on her desk and Father O'Brien retrieved one and a pen for her. She scribbled something down and then turned it around for Father O'Brien to see.

His name is John.

She then opened her mouth, but still no sound came out. The priest gave a mirthful, raspy laugh, his blue eyes crinkling.

"If only these things were so easy. What I really meant, Johanna, is that St. Zachary's loss of speech was brought on by his refusal to believe in the word of God, brought to him by an angel. Though St. Zachary was brought the glad tidings that he would soon have a son, he thought only of his and Elizabeth's age and their infertility, not the word of God. He didn't believe that, with God, all things are possible. And this was with an angel in front of him!

But we don't often deal with signs as straightforward as that, and our silences are often much more about the terrible things that happen to us, not the good. What I want to know, Johanna, is whether your silence is because something has happened to you, that 
you are now being mute because you don't believe in yourself and God's power to heal all wounds? Or are you feeling overwhelmed? There are many reasons one might be silent, and I'm hoping that we might be able to talk about it, if you're willing. Know that I can't take confession outside of the church unless your health is bad enough, but whatever we talk about will still be in complete confidence."

He fixed her with a careful gaze. Johanna quickly wrote on the paper again. I don't know what's going on. I just woke up this morning and couldn't talk. And now people are acting weird around me.

"What do you mean?"

It's like they are saying things that they don't mean to say.

"How so?"

It's hard to explain.

"I am willing to listen-or, I suppose, read-if you want to try. Before I became a member of the clergy, I was well on my way to completing my studies as a child psychologist, so I have some experience in the field," he said, smiling reassuringly as if to further qualify himself.

Why did you stop?

"In truth, I grew tired of it and just wanted to stop. My mother had put a lot of pressure on me to enter the clergy—she was a very devout woman. I was still young enough to be seeking her approval and so I decided to listen, and dropped out of my studies and went to seminary. My mother told everyone that I had a vision in which God called me to be a priest, and I never contradicted her story. It made her feel so good to let 
people know that her son was doing something righteous for the Lord, and I was happy that she was proud of me," he said. He then looked at Johanna.

"Well, I see what you mean," he said and grew silent, staring out the window. "I have to go," he said abruptly, and got up and moved toward the door. "Sometimes these things can only be healed by fasting and prayer," he mumbled, giving her a final, concerned glance before crossing himself and leaving the room. Johanna heard him say something to her mother, and then leave. Johanna's mother then came thundering back up the steps. In the doorway, she ripped the tape off her mouth. She winced, then turned an angry eye to Johanna.

"What just happened? Are you lying to me? Can you really speak?"

Johanna got up from the bed and pushed past her mother, heading down the stairs. "Johanna!" her mother yelled, but she ignored her, leaving the house, grabbing her bike and furiously pedaling off into the heat, sticky and thick like honey.

In no time, she found that she had ridden down to the fair grounds that stretched out behind the little group of houses in her neighborhood. Though mostly a field used by the children for a large part of the year, there was always a festival held at the end of the summer. This year, there was a rumor that a circus was coming, and Johanna was greatly looking forward to it. Though she had not been to one since she was a small child, they still held a fascination for her. She remembered being awed by the women on the tightropes, their nimble legs balanced so precisely on the thin rope high above the crowd. It was amazing, how those muscles and sinew seemed to be completely in harmony with that taut rope, but one move out of that delicate dance with gravity could be the 
difference between life and...well, a net, but the hint of death was what made it exhilarating and horrifying for her.

As she neared the grounds, she saw that they had begun to set up tents to have the grounds ready by the end of the week. There were a few men milling about, running between trucks and trailers as they worked to begin organizing the different stations. The large, white tent where the circus would take place had already been set up, and Johanna felt a tingle of excitement. She decided to go down and see if she could catch a glimpse of any of the animals. She rode down the hill, the tall grass whipping at her feet while she enjoyed the giddy rush of her stomach leaping and plunging with the shift in gravity. She came to a rest at the bottom and set her bike on the kickstand.

No one seemed to pay any attention to her as she neared the large tent. The men were running busily about, some shouting orders, and Johanna found herself strangely enjoying being unnoticed amidst the chaos. When she reached the great tent, she stood in the opening, staring at the dark, empty space inside and imagined the lights, bleachers, central rings, and possibly even a tightrope that would soon be filling the space. She could almost hear the people laughing and gasping in delight and amazement at the tricks, much like she had when she was a child. She reached up and felt the flap. It was warm from the sun, and she could see that there was an arabesque design that lined the entire entry, but it had been faded by years of use and dirt, and whatever color it had been had now become nothing but a dusty brown. She traced the outlines with her finger, feeling the beautiful loops and swirls until their trails crawled too high for her hand to reach. 
"It's very beautiful when it's been cleaned," said a voice from behind her. Johanna jumped and turned to see who had caught her.

A few feet away from her stood a tall and lanky man, with dark hair and skin that had been tanned from the sun. He was watching her carefully, and waved a thin arm at her in greeting. "Sorry, I didn't mean to scare you. You live in this neighborhood?" Johanna glanced up the hill toward the smattering of houses beyond the field and nodded. He took a few steps closer. Joanna could now see that his eyes were dark like his hair, and there was something odd about the way his lips set on his face, as if he had possibly been hare lipped at birth. Though there was something about him that was handsome, Johanna also felt a bit unnerved by his presence.

"I said I didn't mean to scare you. You don't have to be so quiet. I don't bite. In fact, I was going to see if you were okay. You seemed sad. But you shouldn't be here. Too many ways a pretty little girl like you might get hurt." He tried to offer a friendly smile, but it didn't quite reach his eyes. He took another step closer.Johanna backed against the warm tent flap. 'Hey, you're a real charmer, aren't you? I like the quiet type. What's your name, girl?" Johanna pointed to her mouth and then shook her head.

"What? You're a mute?"

She nodded. Close enough.

"Well, Mute Girl, my name is Jerome, but you'll probably hear me called Klaus. That's my stage name. I'm a knife-thrower. You ever seen someone throw a knife, Mute Girl?”

He inched closer, and Johanna looked nervously around. All of the workers seemed to have disappeared for the moment. She glanced toward her bike, sitting at the 
bottom of the hill. She could make it if she ran as fast as she could. He paused. "I said I don't mean you no harm, girl. You're like a rabbit waiting to split. But you didn't answer my question. You ever seen a knife show?"

She shook her head.

"Well, you know, some men, they take the easy way out. They just pretend to throw the knife, and palm it while you're looking on at that poor girl strapped to the board. Then, some device on the back just pops up blades from the back of the board, so it looks like they've landed. And everyone oohs and ahhs like they've seen real magic. They're a bunch of phonies. But me, I don't mess around with that. You see, Mute Girl, it's not so hard to learn to throw accurately. You just gotta practice. Maybe start with smaller targets that are easier to come by, that won't be missed. Straycats, dogs, and maybe even some small, frightened rabbits." With this, he gave her a wink. "You learn how to handle the blade, feel the way it curves into the deadly point. You get a sense of how to guide it, send it true to its mark. Then you work your way up. I'm real good, Mute Girl. Haven't missed a mark in fifteen years. And the last one I missed, she ain't talking."

He gave another lupine grin and moved closer again, this time within reach of her. She could smell him, his cheap cologne and sweat.

"You know what? Audiences love a pretty volunteer to help out. You think you might wanna come up on stage? I promise you'll be fine. What do you think about that, pretty Mute Girl?"

Johanna shook her head and began to slide sideways to her bike. She wanted to yell, to scream, but instead could only continue shaking her head as she finally broke into 
a run. She didn't look back to see if he was following her until she was at her bike. She turned as she flipped the kickstand up, ready to race up the hill and head back home.

Klaus still stood at the entrance to the tent, watching her with a grin on his face. "You and me, girl, we're gonna have a lot of fun!" he called. Johanna did not look back again.

She rushed through the rows of houses, not really wanting to go home, but also not wanting to go anywhere near the fairgrounds and Klaus again. As she got close to her house, however, she saw that there were people gathered on her front yard with her mother. Johanna ducked behind a bush, hoping it and the fading daylight would hide her from sight. She watched them from her hiding place. They weren't talking; they all seemed to be waiting for something. And suddenly she knew. They were there for her. Something about the way people had been speaking to her had made her realize there was something else to her freak silence, that people were losing control around her, and these strangers on her front yard had to be there to investigate her. Maybe Father O'Brien had called them.

As she rested on her bike seat, considering her predicament, she saw the widow behind one of the houses, slowly heading up the dirt road back toward her house. Johanna, afraid to return home because of what might happen to her, felt the urge to follow the widow. Maybe she could hide at the widow's house. Maybe the widow even knew a way to help her. Quickly, Johanna sneaked between the houses, ditching her bike in the side yard, and began to follow the widow down the winding dirt road. 
II.

When Johanna finally reached the widow's house, the sun had sunk low behind the trees, and the sky had turned a deep shade of navy, dotted with stars. She stopped for a moment. She had never actually seen the widow's house up close before, tucked away as it was in the woods. When she was little, she and a few other neighborhood children would sneak away into the woods and try and dare each other to go near enough to knock on the door. No one ever made it into the clearing, though. They always hung back in the safety of the trees, watching the house for a few seconds before running back to the safety of the group, no matter how many names they were called or punches they received for not finishing the dare. Johanna herself had been reluctant to play, and insisted that it was rude to bother her. The others thought she had a polite way of being scared.

Now, she stood facing the house, well beyond the safety of trees. It was a small cabin, and Johanna could see that it was well taken care of. A row of flowers followed a series of stones up to the front door, and Johanna briefly wondered who tended to them, or if the widow got out there and did it herself. Johanna raised her hand to knock on the door, but then stopped. What if the widow didn't want company? What if she couldn't help her? What if she did eat children? The last thought was nonsense, Johanna knew, 
but, then again, the rest of her day would have easily fallen into that category, as well. Ignoring the nagging fear, she knocked on the door. It opened almost instantly.

"You were the one following me," the widow said. "I could hear you from a mile away."

Johanna opened her mouth, but she wasn't sure she would've been able to speak, even under normal circumstances. This was the closest she had come to the widow. She was a small woman, but she still stood completely straight, not stooped with age, and it made her seem taller. Her gray hair was pulled back, flowing down her back, and, though Johanna had always believed her to be extremely old, she could still see black running through the hair. The widow crossed her arms and set her lips into a firm line, and Johanna almost felt that she was being evaluated behind those black glasses, even though she knew the widow couldn't see her.

"What do you want?" the widow asked gruffly. Johanna shook her head. The widow reached toward her and grabbed her face, pulling her head closer. Her hands briefly rested on the side of Johanna's head before moving forward, feeling Johanna's cheekbones, her forehead, her nose, her mouth.

"I don't know your face," she said, sounding puzzled. "What do you want?" She still held one hand to Johanna, feeling Johanna's furrowed brow. Johanna mouthed wordlessly, and the widow's hands traveled down her face, cupping under her chin to feel her mouth moving. The widow nodded, biting her lower lip. "I see," she said, as if that solved everything. After a moment of contemplation, she said, "Please come in," and stepped away from the door. Johanna hesitantly stepped forward, and the widow placed her hand on Johanna's back, guiding her in. 
Johanna was immediately greeted by the smell of bread and a hint of the sweet vanilla smell of orchids. The widow moved past her, heading for what seemed to be a kitchen at the end of the hallway. The hallway itself was sparse. In the dim light, Johanna saw no pictures or paintings lining the off-white walls. The only decoration was a small, wooden table with little trinkets and figurinesscattered over the top. Johanna saw that almost all of them were insects made of colored wire, small butterflies and beetles gleaming in shades of blue, green, red, and purple. She wondered who had made them for the widow, arranged them so lovingly in the hallway. Despite its relative plainness, something about the house felt warm and inviting, and Johanna followed the widow into the kitchen.

The room was lit only by a few candles, and the widow was pulling down a mug from one of the cabinets. Johanna sat at the edge of the kitchen table, watching the widow move around the kitchen with amazing ease. Johanna thought briefly of all the work it must take to order everything so that its location was known at all times, of the years of bumped knees or scraped hips as the widow moved about her house and learned the feel of it, where to put her feet and where to avoid the pain or aggravation of objects. Johanna briefly thought of what would happen if something moved only a foot from its location, and then immediately felt guilty.

"Would you like some tea? Or maybe some coffee? I've got both. Knock once for tea or twice for coffee," the widow said, turning to her. Then, as an afterthought, she added, "Sorry about the lighting; in my condition, you don't seem to need much." Johanna rapped once on the table, and the widow nodded and grabbed a metal tin from the counter, scooping some leaves out and sprinkling them into an infuser ball before 
dropping it in the mug. She filled a kettle with water and then carefully placed it on the stove. She turned from the stove and sat at the table. They sat in silence for a moment, and Johanna found herself wishing she could speak, or that somehow the widow could read if she wrote a note. She felt a need to explain everything to her, that the widow would know how to solve everything.

“Are you mute?" the widow asked abruptly. Johanna knocked on the table once.

"I will take that to mean yes. Hit twice for no." She waited a moment to confirm that Johanna had meant she was mute. When Johanna stayed silent, she nodded. "Are you from this neighborhood?"

\section{Knock.}

"Are you in trouble?"

Johanna pondered this for a moment, and then decided that, though she didn't feel immediate danger, that there was certainly something strange about the group that had been gathered outside of her house.

\section{Knock.}

The widow seemed to reflect on this for a moment, her thin bottom lip tucked under her top teeth as she thought. "Have you always been mute?"

Knock, knock.

The tea kettle began to whistle, and the sudden shrill sound may Johanna jump. The widow hobbled over to the stove and poured the water into the mug before returning to her seat.

"While that steeps, I would like to figure out your name. Would you mind coming closer?" 
Johanna stood up and brought her chair around the table. She sat close to the widow, and caught the scent of orchids again. The widow laid the palm of her hand on the table. "Will you spell out your name into my hand?"

Johanna leaned forward slowly, her hand gently touching the widow's palm. Her hands were rough with callouses, and Johanna was reminded of tree bark. She began to trace her name.

"Slowly, if you don't mind. It's been a long time since I've done this." Johanna started over, moving slowly, carefully, making sure to make the subtle differences between the " $\mathrm{H}$ " and the " $\mathrm{A}$ " apparent in her touch.

"Johanna?" the widow finally asked. Forgetting for a moment, Johanna knocked into the widow's hand instead of on the table. The widow smiled, and briefly grasped Johanna's fist before letting her go. "It's a pleasure to meet you Johanna. You are one of the children who used to play in the woods around my house, aren't you? I seem to remember that name being called out often."

Knock.

"Let me get your tea," she said, and once again returned to the counter. "Would you like some sugar?"

Knock.

The widow dropped a couple of cubes into the mug before bringing it over to Johanna. Johanna stirred for a moment and then took a sip. The tea was strong and had a minty flavor that was almost instantly soothing. Johanna took another sip.

“Something tells me that you didn't stop by tonight just for a visit. You're worried about something. Is there something I can do to help you, dear?" 
Johanna took her hand again and spelled out, Not sure.

"Can you tell me what's happened?"

And so Johanna slowly explained her situation to the widow, etching out the strange events of her day in the widow's palm. The widow would repeat every word out loud when Johanna finished spelling it and, by the time she had gotten to her decision to follow the widow, the bright moonlight had tracked its way from one side of the kitchen to the other. Johanna yawned loudly when she finished.

"Goodness, you must be so tired. I'm sorry that I've kept you up this long. You can stay with me tonightofcourse. I'm afraid I don't have much for guests, but I've got a cot and a spare blanket and pillow, if that will do."

Johanna rapped on the table and the widow got up to find the cot. Johanna grabbed her hand before she moved away from the table and wrote, Thank you.

"It's not a problem, dear," the widow said, patting Johanna's hand. She left the kitchen and Johanna heard her open a door in the back room of the small house, and she soon reappeared with the cot. Johanna hopped up and helped her place it on the floor. The widow then went to get some bed things for Johanna.

"I hope this will do. I'll let you get to sleep now, and we'll talk more when you wake up tomorrow." The widow started to leave the room, but then stopped in the doorway for a moment, as if she wanted to say something. Her head turned toward Johanna, and for a moment, Johanna thought she saw sadness and worry work its way into the widow's face, but it was quickly replaced by the hint of a smile.

"Goodnight, dear." 
Johanna lay in the cot, and realized that she was exhausted. The thought briefly struck her that the widow was the first person to speak to her normally all day, but, before she could dwell on it further, she was fast asleep.

\section{$\#$}

Johanna floated in a sea of stars. She was back in the vast ocean again, but the water was calm around her, perfectly mirroring the night sky above her. It was filled with activity, the electric blue and brilliant white bursts of a new sky forming above. Johanna watched as the water moved in small ripples outward from her body, tiny waves sending chaos flowing through the already changing universe. As she watched the scenes take place before her, the widow appeared beside her again, sending the universe into further disarray.

"Why have you come here?" the widow asked. Johanna tried to reply, but she heard the whistle of the wind in her mind again, and found she still couldn't speak.

“The universe has given you a gift. Don't run from it. Figure out how to use it. There are thousands who are suffering; do what you can to ease their burden," the widow said, and she skimmed the surface with her hand. Stars radiated outward from her touch.

Johanna nodded, unsure of what to do. The widow just smiled, and turned her face toward the sky, her eyes closed. She smiled lightly and stayed that way for a moment, enjoying the silence. Johanna imagined she could hear the boom of the universe unfolding above her. Finally, the widow opened her eyes, and they shonelike sunlight in the dark sea. 
When Johanna awoke, the kitchen was filled with sunlight. For a moment, she felt she was still afloat in the sea, but then she gathered her bearings and remembered where she was. As if she had heard her stirring, the widow appeared in the doorway.

"Are you awake?" she whispered, voice quiet so that Johanna might still sleep through her talking if she was just turning in her sleep.

Johanna knocked on the wall.

"Good, I was just wondering if you were going to sleep the day away. It's my fault for keeping you up so late last night. Are you hungry?"

Johanna had not eaten much at all yesterday, and realized she was starving. She knocked again, this time a little more emphatically.

"I thought you might be. I'll see what I can put together for you."

Johanna stood and reached for the widow's hand.

\section{Can I help?}

“Oh no, don't trouble yourself. Just sit down and relax. And here, take this." She handed Johanna a basket with slices of bread and butter in it. While the widow busied herself at the stove, Johanna sat back down at the table. As she spread butter on her second piece of bread, Johanna thought about the dream she'd had. The details were hazy, but she remembered that the widow had told her to figure out what her silence meant. Yesterday, it seemed that all the people she encountered-her mother, Dr. Ratliff, Father O'Brien, and the knife-thrower-had all told her something secret, but their reactions had each been different. Why had they told her what they did? And what was Johanna supposed to have done for them? 
Before she could become too lost in thought, though, the widow announced that her food was ready. She handed Johanna a dish piled high with rice and chicken mixed with fresh vegetables in a red sauce Johanna did not know the name of, but it tasted of garlic and sage. Johanna thought it was one of the most delicious things she'd ever had, and happily ate the entire helping.

When she had finished and put her fork down on the table, the widow took a seat next to her.

"I've been thinking about what's happened to you, Johanna. It reminds me of a story I used to know from when I was a child. Do you mind if I tell it?"

Knock, knock.

"All right, well, there was once this young girl who could see the future. She would get these burning visions that would temporarily blind her, and instead she would see scenes of things that would come to pass. Sometimes they were very important things, like droughts or death, and sometimes they were more simple-births, a visitor coming. And although her family was very spiritual, they believed that her visions were the work of evil, that she shouldn't be able to see beyond what a normal human could. So, in an act of fear, the girl's father and brothers put out her eyes, believing that she would no longer be able to see the future with them gone.

"And for a while, the little girl was free of the visions. As she went on about her life, learning how to live without sight, she experienced a remarkable improvement in her hearing. One day, while she sat in a field feeling the warm sun on her skin, she heard the earth speak to her on the wind, and it whispered to her again of things to come. She was terrified this time, and tried to keep it secret from her family. Eventually, though, it came 
out, but instead of reacting in fear again, they realized that providence must have wanted this child to be a seer, and so they began to listen to what she was told, and she became a very respected and revered member in her village.

“This is, of course, just a silly legend, and there's no truth to it. But, still, when I lost my eyesight when I was a little girl, I had to learn to hear better. So, Johanna, you have lost your voice and people have begun to speak to you in a new way. Just like that little girl, and just like me, you must learn to make the best with what you have been given."

Johanna reached for the widow's hand. I'm afraid I won't be able to. I'm just a kid.

"You'll figure it out in your own time."

Johanna knew she had to go back to her mother's, to face whatever it was that that group had waiting for her. She wished that she could take the widow with her, that she would somehow provide protection against whatever was waiting for her back at home, but she knew that this was something she needed to face alone. The widow had already done more than enough for her.

I know what I have to do. Thank you for letting me stay and for your help. Is there anything I can do for you?

“Oh, no, it was my pleasure. I haven't had a visitor in years. If you need me again, you can find me here."

Johanna squeezed the widow's hand and got up from the table. The widow followed her out, standing in the doorway like she was watching her go. Halfway through the clearing, she turned back to the house. The widow was still at the door, her gray hair 
wild and loose, her arms folded over her chest. Johanna wondered how such a small woman in a little wooden house could put so much fear into the children in her neighborhood, how she could ever be viewed as a witch. Unlike them, Johanna felt a pang of sadness for how lonely the widow must have felt, all alone in the house out here, separated from the rest of the neighborhood. Hoping that maybe she might come back again soon, she turned back to the forest and made her way to the dirt road that would lead her back home.

When she made it back into her neighborhood, Johanna retrieved her bike from her neighbor's side yard and walked it down her street. At her house, she saw that there were several cars parked in the driveway, and even more along the curb. She dropped her bike in the yard, not caring that her mother always insisted it go inside the garage. When she opened the door, she heard several voices coming from the kitchen. They silenced at the sound of the door.

"Johanna?" her mother called. Johanna shut the door in response. Her mother came into the foyer. She narrowed her eyes at Johanna and crossed her arms in front of her chest. "Where have you been?"Her jaw clenched briefly, but she then attempted a smile and reached out her hand, placing it on Johanna's shoulder. "I've been worried, that's all."

Johanna shrugged out from under her mother's hand and nodded toward the kitchen.

"We've had a few guests come by. It seems that more may be coming. Father O'Brien, after discussing your situation with a few members of his parish, has called a 
few others over. And we've just had some more guests. They're all waiting to see you. Will you go and sit with them?"

Johanna looked past her mother, toward the lights of the kitchen. She heard murmuring, and briefly longed for the quiet of the widow's cabin. With a sigh, she nodded and followed her mother into the kitchen. 
III.

For the first few days, only small groups of people arrived at the house-some neighbors, then friends or relatives of the first people Johanna had met with, curious to investigate what they had been told. But then, more started to trickle in, cars started to fill the street, and Johanna was removed from the kitchen to the more spacious living room to meet with the "visitors," as her mother had taken to calling them. Johanna's written response-“"Spectators"- had not been received well.

As more people gradually filtered in to see her, Johanna started to learn more about her "gift." She had suspected from the encounters with Dr. Ratliff and Father O'Brien that most people, when they spoke to her, felt some relief in unburdening themselves. Johanna knew, too, that that relief went deeper than a purely emotional level-it was not as if she'd suddenly become the world's most gifted therapist. When she listened to these people, something like a charge ran between her and the speaker, a quietly electric thing that would unknot these worries and bring them out of people, opening a channel that felt like it had the power to physically heal.

She found that this channel was only really effective when she and the person spoke one-on-one. If more people got involved, it was like there were too many frequencies battling for the same space, the charge would fade, and Johanna would slip into the background, exhausted. It seemed she wouldn't be having group sessions any 
time soon. Instead, she found herself face-to-face with stranger after stranger (with a few familiar people from around the neighborhood thrown in), and her mother ran each session at a strict three minutes. She would set her watch as soon as the person entered the room, exiting quickly, only to swoop in as soon as the second hand hit the mark, pulling the next person in as she ushered the old one out.

Soon, though, the number of people started to become overwhelming. Her mother was getting up earlier every morning to prepare more heaps of sandwiches and drinks for the guests, to the point where she almost didn't sleep at night. Johanna was given fewer breaks between people and grew more tired by the day. Afraid that she might punch the next person who told her about the time they cheated on a test, she sneaked outside on one of her brief breaks. She wandered over to the garden, now slowly starting to rot in the heat. The bugs seemed to have overrun the tomatoes. She looked around for a good place to hide for a spell. If she went behind the tomato poles, by the patch of peppers, she might not be immediately noticed.

Sighing heavily, Johanna lay down next to a pepper, its rotten skin like another mouth, a black pucker ready to spill yet another secret to her. Johanna closed her eyes and welcomed the quiet. The heat of the sun boredown, and her skin began to bead with sweat. As it slowly began to roll, Johanna imagined that each droplet was a secret spilling from her. With each one that freed itself from her skin, she would be lighter. It was a crushing realization, then, when she figured that she would need to sweat an ocean and set herself adrift, before she could even come close to getting rid of everything. Instead, she decided that each bead was a part of her, and little pieces of her were rolling off and seeping down into the ground. She would eventually dissolve, become a part of 
the dirt and grass and be filtered up by one of the roots around her. She imagined growing into one of the peppers, spicy red and free of the death that hung on their wrinkled skins now. Or maybe she would be one of her watermelons. But she couldn't. She would be so full, would burst open, secrets and frustrations spilling out in little black seeds. What she really wanted was to grow into a beautiful oak like the ones at the edge of the forest. Then the wind that rustled through her leaves and buffeted the branches would bear her secrets, steadily carrying them away from her every season of her life. But she would be happy, silent and proud through all of her years. She had just begun to imagine the deep auburn of the leaves she would have in the fall when a shadow fell over her.

"We need to talk," her mother said. Johanna sat up in the grass, afraid that she was in trouble for hiding. But her mother didn't immediately scold her, instead just crossing her arms and looking down at Johanna. She didn't join her on the ground.

"They want to have a meeting to see what to do about you. Some people apparently aren't comfortable with the idea of you. With whatever it is that you make people do."

Johanna just shook her head in confusion.

"Get up."

Johanna remained on the grass. She was not going anywhere until she was sure that this meeting was not some way to burn her at the stake like she was some sort of witch.

“Get up." Her mother reached down and grabbed her by the arm, nails digging into her. Johanna jerked her arm back and cradled it to her chest, glaring at her mother. 
"Stop being such a brat and come on!" her mother snarled, grabbing her once again and pulling her to her feet. "People are overrunning our house and our neighborhood because of you; the least you could do is show a little courtesy and come to this meeting."

Johanna glared at her mother, but didn't resist again.

"That's better. Now, let's go."

\section{\#}

They had decided to hold the meeting outside as there were too many people to fit in the small town meeting hall. When Johanna and her mother arrived, Johanna saw that people had apparently grabbed whatever furniture they could and organized it into the center of the field, a mass of fold-outs, wingbacks, wooden chairs, lawn chairs, and recliners. A few people had even dragged tables from their houses and set them up on the perimeter, loading them with platters of cubed sandwiches, bowls of fruit, and jugs of water. Although Johanna thought it almost offensive her fate was being decided at a neighborhood potluck, she was at least cheered by the presence of the refreshments. She didn't think that anyone would want to string her up while snacking on pimento cheese.

People stared at her as she and her mother approached the tables. Without a word to Johanna, her mother dropped her arm and walked to the end of the table where a group of women were talking, each eying Johanna suspiciously.

For a moment, Johanna looked around at the crowd. She had never felt so obvious and yet so small at the same time. She wished that they would just send her away. She was unwanted, some kind of monster. She backed away from the maze of chairs until she 
hit the tables, trying hard not to start crying, to look strong in the face of whatever was coming.

As she stood against the table, another woman approached her, smiling encouragingly. Johanna was not sure who she was, though she felt like she had seen her before. She put a hand on Johanna's shoulder when she got near, giving it an affectionate squeeze.

"Johanna! Would you like something to eat, dear?" The woman turned to the table without waiting for an answer and immediately began stacking up some of the snacks. She thrust the plate of food at Johanna, and the stack wobbled like the curls on her head did as she talked. "I made these coconut pastries myself. Secret family recipe. Though, of course, I suppose now you know that it's a dash of dark rum and an extra tablespoon of vanilla, don't you? What with you being able to read minds and all."

Johanna choked on the fluffy pastry. The woman gave her a concerned look and patted her on the back.

"Don't eat it too quickly, dear. All those coconut flakes will go down the wrong pipe. Then who will be our resident psychic?" Johanna shook her head, but the woman continued, talking at length about her family's cooking (Johanna had finally realized that the woman was one of the bakers in her neighborhood) and kept asking Johanna what it felt like when she read someone's mind, but then she would move on, paying not even the slightest attention to Johanna's attempts to mime corrections. Finally, she concluded, "Well, I must get seated. They'll be starting soon. Honestly, I don't know what the fuss is about. You seem perfectly fine to me. I'm sure that, once everyone sees that, they'll stop 
getting so riled. No need to worry, dear." She flashed another reassuring smile before shuffling away to find a seat.

Someone tapped Johanna on the shoulder. She turned and an older man pointed her in the direction of a chair set facing the mess of furniture in the center. As she took her place, one man stood up in front of the crowd. The sea captain. He usually ran these kinds of neighborhood events, although Johanna always found him somewhat odd, as if he had spent so many years with his crew out on the ocean and amongst its many strange inhabitants that he had forgotten how to deal with the land's equally, but differently, strange inhabitants. Still, there was something authoritative about his presence, and people seemed to believe his years of commanding the ship meant he was the perfect person to command such meetings. A hush fell over the crowd as he began to talk in his hoarse voice. It always made Johanna think of the ocean, the salty air brining his throat, eroding his voice until it was lowered to its current rough sounds. To hear his real voice, she thought, would be like a siren's song.

"I trust that we all know why we are all here today," he started. His voice sounded more natural in the open air than it ever had inside. "Over the past couple of weeks, something strange has happened to one of our children. As you have no doubt noticed, it has drawn the attention of several others. The task we face today is to decide what to do about this. This is, as always, an open forum for discussion, but please note that the girl cannot speak, and thus cannot make an argument for herself. Instead, we are relying on the testimonies of others as to her effect on them. I'll open it up now for you to discuss." 
For a moment, no one spoke up, but there was a hushed murmuring as people whispered amongst themselves. Finally, a woman stood up near the back. Johanna had never seen her before and was not even certain she lived in the neighborhood.

"What happens? When she does it, I mean. People have been saying that they end up saying things they've never told anyone to her. How does she do it? What happens?"

A few people looked around, waiting for someone to answer. No one did. Instead, a man stood up on the other side of the crowd.

"Why does she need all of these secrets? What does she do with them? I'm not sure I'm comfortable having my family around her. I don't know that anyone should. What if she tries to use something against us?"

“They said she couldn't speak! How's she going to tell people?" someone else called from the crowd. Johanna couldn't see who.

"Well, her hands seem to work fine. I'm sure she can write," the man snapped. "I think what's going on here is unnatural!" another voice cried. A few more cheered in response. Johanna wished she could dissolve like she had imagined, that the ground beneath her would immediately draw her in, absorb her completely, but it remained stubbornly resistant beneath her sweating feet.

“May I say something?" a voice called over the rising cries.

Father O'Brien stood in the middle and started to move to the front, clumsily attempting to make it through the chairs. He came up to Johanna and smiled to her before he turned to the crowd.

"I have experienced what this girl can do firsthand. Now, I will admit to you that I was uncomfortable with the whole situation at first. I had just revealed something to her 
that I had never told anyone, something that could have damaged my position as a man of God. But, I tell you now, this girl has made me believe even more in the power of God. "Here we are, debating her like she is some sort of abomination. What I think we have been given here, what we are trying so hard not to see, is a miracle. Instead, we're gathered around her with stones in our hands, ready to cast them. But Jesus had enormous faith in the power and the goodness of the people who followed Him, especially those that He has deemed worthy of his gifts of healing.

"When she and I talked, I felt something go through me. And even though I was terrified and embarrassed, I also felt more relief than I ever had before in my life." The murmur in the crowd had shifted now, buzzing less with fear and anger, the tone lighter with the hum of curiosity. Father O'Brien moved closer to the crowd, pacing back and forth across the front row as if searching for someone. "Dr. Ratliff! Is Dr. Ratliff here?" he called.

From the back left, Dr. Ratliff rose. Johanna didn't know how Father O'Brien could've missed the bright red flowers on Dr. Ratliff's Hawaiian shirt. "Here," Dr. Ratliff responded.

"Dr. Ratliff! You, too, had a discussion with Johanna, correct?" "I did."

"How did you feel?"

Dr. Ratliff paused, crossed his arms over the curve of his belly. "Good. Like I was free of something," he said after a moment. Father O'Brien nodded.

"History has taught us that many who were blessed were persecuted because others failed to recognize what God had put before them, that they were so concerned 
with their own petty smallness that they didn't recognize or accept greatness. We need to let this girl be a miracle. We need to give her that chance."

Some people began clapping, but then another voice roared, "She's a freak!" The crowd hissed again with nervous chattering. The captain stood up again and held his hand out to silence everyone. He approached Johanna, pulling a pen and a piece of paper from his pocket.

"What do you want to say, Johanna?" he asked her quietly. She took the pen and paper from him and began to write. The crowd was rapt, watching her in silent attention. She handed the captain the paper, and he held it up to his face and turned to the crowd.

"I just want to help," he read. "I'll leave if people want, but I just want to help." The quiet remained as the crowd let her answer settle in. A few heads began to move as people whispered back and forth. Then she noticed that people were turning around and looking at the opposite side of the field. She looked out over the crowd and saw that another group had formed at the edge of the field. She recognized the tall man at the front. Klaus.

"Let her come with us!" he yelled. "We have room for her. We can put her up in the tent, and people can come to see her there. People will come from all over the world to see her!" He grinned at his audience. "If, like the good preacher said, God has put her here for a reason, then let's put her somewhere where she'll be noticed!" A few people clapped, but he waved the applause away. "And, I suppose, it may get her a little bit further away from your children, for those of you who are inclined to be scared of this poor little girl," he added, feigning a look of sympathy. 
Many faces turned to look back at her, considering. She shook her head, tried to indicate that she wanted the pen and paper back, but the captain was not watching.

"If nothing, this will at least give you all more time to discuss a more permanent solution," Klaus concluded.

"Let's put it to a vote," the captain said after a quiet moment of consideration. "All those in favor of keeping her in the neighborhood, please raise your hand."

Johanna watched as only a few people raised their hand. Father O'Brien looked around at the crowd, incredulous. Johanna noticed that her own mother had not raised her hand.

"All right, now all those in favor of accepting Mr...?"

"Klaus."

"All those in favor of accepting Mr. Klaus's offer, please raise your hand." Almost every hand in the audience shot up, including her mother's. Johanna's clenched fist flew to her mouth, and she had to bite down hard to keep from crying.

"We have a clear majority decision. She will stay at the fairgrounds as long as they see fit or until we reach a majority on an alternative."

Trembling, looked around pleadingly for someone else to stand up, to intervene. Father O'Brien hung his head. She leapt out of the chair and ran to the captain, pointing wildly at the pen and paper. She needed to tell him that it was dangerous for her there, that Klaus had threatened her. But the captain only shook his head at her.

"I'm sorry, Johanna. I can't overrule this decision, no matter how much I'd like to. A mutinous ship is an ungovernable ship, even when you're on land." 
He turned and walked into the dispersing crowd. People were taking their myriad pieces of furniture back to their rightful places. Johanna's mother approached, maneuvering around a couple moving a particularly large, red recliner. Johanna shook her head frantically, pointing toward Klaus's group.

"Oh, stop," her mother hissed, slapping her hand down. "Can’t you see that you're being such a burden? Why can't you just be normal? That's all I ever wanted. I've tried to convince myself for years that I love you, that what I feel for you is the thing that I hoped for when I prayed that I would have a child and be better than my mother. But the truth is, from the moment they forced you into my arms, crying and covered in my own blood and shit, I felt in my heart that you would be nothing but a disappointment to me."

For a moment, her mother's face had an expression that looked like relief, but that quickly vanished as the words registered. Then, her eyes grew wide and her hand flew up to her mouth.

"Why did you do that?" she asked, her voice only a whisper now. "Johanna, I -" Johanna didn't know that her hand had moved until it connected with her mother's mouth. Her mother's head jerked to the side and Johanna stepped back, terrified. But then she wanted to keep going, to keep hitting her, as if she could funnel all of her rage and confusion into each of her small fists and empty them with each blow. Her mother set her jaw, but didn't retaliate. Instead, she just nodded.

"It's time to go," her mother said. Johanna, fuming, returned the nod. She turned and looked at the group waiting for her. Klaus was smiling, watching her. She felt a small 
shiver run through her in response, her body running its warning down her spine in protest to the hungry way his lips curled above his teeth.

Johanna wondered where the widow was and desperately wished that she would suddenly appear, but she knew that was just a silly hope. Forcing back her tears, Johanna hung her head and walked toward the group.

Klaus stepped forward to greet her. He smirked, his tongue briefly darting over his teeth, running along the sharp ridge of one of his canines.

"I've been waiting to see you again, little Mute Girl. We've been all alone down in our tent, waiting for the crowd, but it seems they were all interested in something else. But, that's okay. We're all together now. I told you we were gonna have some fun."

Johanna ground her teeth so hard that she was sure they would split, but she didn't look away from his gaze. If her mother was going to abandon her here with this man, she was going to hold her ground and not fall apart.

"Let's go get you set up," Klaus said, and turned back toward the houses. 
IV.

Once theyarrived at the grounds, Klaus and the others led her straight to the small, silver trailer at the edge of the field. He turned to face her and threw his arm out theatrically, presenting the trailer like a prize.

"Welcome to your new home," he laughed, a wheezing staccato. Johanna nodded, but hung back, staying with the group of quiet performers. "Don't be shy now, girl. Go on in and check her out." He motioned her forward, and she looked nervously around to see if someone from the group would come with her. They remained still. "I said c'mon!"

Johanna stepped forward and he shepherded her in through the front door, ducking in behind her. He flipped the light switch and the ancient bulb crackled and buzzed, but didn't die. Johanna paused and looked around. The trailer was sparse, but cramped. Immediately in front of her, there was a countertop and a tiny stove, with a table and a small blue booth occupying the right end of the trailer. A couch ran alongside the wall to her left, leading up to a closet and a bathroom, with a bed in the very back. She was suddenly aware of Klaus looming behind her, monstrously tall in the tiny doorway. She unconsciously backed away, bumping up against the edge of the table. He didn't seem to notice.

"Well, how do you like your new digs, Mute Girl? It's not too fancy here, but they'll be treating you like a queen soon enough," he said. He looked around the trailer as 
if he had never seen it before. He ran a long finger across the countertop, then opened a few of the drawers. He smiled when he found a streak knife. He picked it up out of the drawer and examined it for a few moments. It was blunt from years of use, the serrated edge now nothing more than a blank memory of theformerly sharp notches. He tossed it between hands for a moment, and then began to twirl it between his fingers, the blade a fast dancing gleam in his hands. He finally looked her in the eye and approached her corner. Johanna pushed herself further into the edge of the table.

"I ain't gonna touch you, girl, so stop trying to push your way out the damn wall," Klaus said. "I just came to see you get settled and make sure everything is to your liking. I know today must be weird for you, with your mama letting you leave and the entire town voting to whore you out to us."

Johanna didn't know what to do. She looked around briefly to see if there was something she could arm herself with, in case he was just lying to calm her. There was nothing on this side of the trailer, not even glass salt and pepper shakers. Were any of the others still outside? Could she make it to the door quickly enough?

Klaus let out a small roar and threw the knife. Its dull edge hit the wall and bounced off, taking a chip of the fake wood paneling with it. Klaus took two steps forward and leaned down over her.

“Listen, girl. If I want you, I'll have you. But I said I ain't gonna touch you and I meant it. No, I'll wait for you to come to me. You think you're not, but it'll happen. You're gonna get out there and people are gonna fill you up until you're burning alive with all of their bullshit, and then you'll come to me. You'll be bursting from the inside and you'll come to me and beg me for release. Until then, little Mute Girl, I'm just here 
to make sure you're comfortable. You're about to be the greatest show on earth." He threw his arms out dramatically againas his mouth split into another toothy grin.

"I'll be locking the door from the outside. But, should you find yourself needing something, Oliver will be outside standing watch. Don't try to run. The kid is the fastest I've ever seen. He'll bring you breakfast first thing in the morning. 'Til then, just try to enjoy your new surroundings. I'll be seeing you soon," he said, and turned away from her. He let the door slam behind him, and Johanna heard the click of a padlock. She hopped from the edge of the table and looked outside. Klaus paused and spoke to one of the men in the group, handing him a key. The man nodded and broke off from the group, coming up and standing next to the trailer. The others headed away with Klaus. Johanna hadn't noticed this young man before when she was walking with them. He must have been further in the back. She couldn't see much about him in the fading light, but then he turned to face her. She ducked down quickly and waited a few seconds beforepeeking back up. He was still watching her. He winked and gave her a lopsided grin, offering a small wave. She hesitantly waved back. He turned back away from her and resumed his watch on the grounds.

Johanna sighed and returned to the table and sat in the booth. She glanced down at the knife that had fallen beside her. She looked up at the notch in the wall and wondered if the old knife, if forced, could cut through flesh, and whether she even had it in her. She sunk heavily into the fake leather, the fabric giving a dry squeak as it shifted around her frame. For the first time since she had woken up without a voice, she allowed herself to let out the despair that had been fighting to escape. She opened her mouth and released a long stream of rasping air, her frustration and sadness rattling through her. She did this a 
few more times, sobbing silently, before she got up and turned the light out, retreating to the back room and the unmade bed. She didn't bother to put the sheets that had been laid out for her on the bed. Instead, she simply grabbed the sheet and wrapped herself up in it, falling onto the mattress. For a while, she listened to the sound of the crickets playing their symphonies and the occasional grunts and snarls from the lions on the other side of the grounds before she driftedoff into a dreamless sleep.

$\#$

It took a week for the fairgrounds to be reorganized. Some of the performers packed up and moved on, looking for the next group they could bring their talents to. The animals stayed, but they were moved to their cages, intended to be something of a side show attraction. Most of the other, smaller tents were taken down and sent with whoever would take them. Once these preparations were made, all attention turned to the enormous tent. It would never do in its current state, all dull with dust and age. They dismantled it and spread it out like one giant cloth on the field. The seamstress was called in, and she and a team of people set to work repairing the tent, dexterous fingers pulling red and gold threads up and down tirelessly. In order to get it prepared in time, they worked in shifts, a team stitching diligently from morning to evening while the others slept, and the next team working carefully by the light of a bonfire. A separate team was dispatched to help feed them in intervals so they could keep sewing, and to mop the sweating brows of those working by the fire at night. Even after they stopped, when the tent was finally ready, their hands would still clasp invisible needles, muscles curled in a continual attempt to patch up the air. 
Johanna watched them from her trailer, day after day, cleaning and recreating the tent's design. Every now and then, the costume designer for the circus would come to her trailer, fussily taking measurements and muttering to himself. He avoided speaking to her, however, and would nervously glance around the room at anything - a chip in the slate-colored Formica countertop, the way the small table next to it appeared to have a wet sheen as the humidity settled in from the open windows, a loose thread on the carpet by the door-rather than try to make eye contact. Though she didn't enjoy feeling as though she made someone so uncomfortable that he wouldn't even look at her, she was secretly glad for the quiet.

The only other contact she had was with Oliver, who would always politely leave her food on the table (and once, a suitcase of clothing and other items sent from her mother) and ask her how she was doing before promptly exiting the trailer and returning to his place outside. She had not seen him sleep since Klaus had told him to stay behind, and Klaus had not returned since the first night.

The day before she was set to debut, Johanna was resting in her bed, inventing a story in her head about who might have lived in the trailer before her. She was just imagining a beautiful young trapeze artist, flying smoothly and effortlessly in the air, when her front door opened. It was Klaus, followed by the costume designer, who carried a white dress.

"I've got a surprise for you," Klaus said.

Johanna wanted to tell him he lacked a real understanding of what made something a surprise. She bit her bottom lip and nodded before standing up from the couch. The designer stepped over to her and held the dress out for her wordlessly. 
"We'll wait outside while you try it on," Klaus said, and he and the designer stepped back outside.

Johanna held the dress up in front of her. It was fairly simple: sleeveless, with a high neckline, and just long enough that it would hit her knees. The only design on it was a thin band of red and gold arabesques, the same ones that ran along the trim of the main tent, nowlooping around the waistline. She quickly put it on, tying the strap behind her neck to keep it up, and looked at herself in the bathroom mirror. The mirror was small, so she stepped back as far as she could, but she could still only see from the waist up. Double checking the strap and twirling it once, she went to the door of the trailer and stepped out.

“Well, aren't you a vision?" Klaus exclaimed with a smile. "They'll just eat you up!” Johanna shifted uncomfortably, turning away from Klaus's gaze. She saw that Oliver was watching Klaus intensely from the other side of the trailer. He quickly looked the opposite direction when he made eye contact with Johanna.

The designer circled her, closely examining each part of the dress to make sure it fit perfectly. Finally, he nodded and, for the first time, looked Johanna directly in the eyes. "You look beautiful," he said with a small smile. Johanna gave a slight bow in thanks. He turned from her and said, "I believe I'm done here," to Klaus. Klaus distractedly nodded, and the designer walked off to another part of the field. Klaus came closer, still examining her.

“Are you ready for tomorrow?” he asked.

She shrugged. 
"You better muster up some more enthusiasm, little Mute Girl. People are gonna be paying to see you, and they want you to be happy to see them. This circus needs that money." He leaned in close, his hot breath on her neck. "Remember, you are mine now and, no matter who you thought you were yesterday, you are only who I want you to be now. So, you better smile, girl. You may be able to make me say anything you want me to, but that means you know things other people don't, so don't give me a reason to question your worth."

He pulled away and squeezed her shoulder. "Let's get you back inside, then." He took the key from Oliver and guided her back inside, locking the door behind her. He knocked on the small window and waved his goodbye, pointing to his face and giving a bright smile. Johanna turned in disgust and went to put on her regular clothes.

A few minutes after Klaus had left, Johanna was carefully placing her dress in the closet when there was a knock at the door. She knocked on the wall of the trailer to let the person know to come in. It was Oliver. Leaning in through the door, he opened his mouth and then immediately looked unsure of himself. He blushed and started to lean back out of the doorway, but Johanna quickly hit the closet door to get his attention. When he looked back in, she gestured for him to come in. He nodded and stepped up into the kitchen area. Once again, he paused, looking uncertain.

"This may have been a dumb idea," he said by way of introduction. Johanna raised an eyebrow at him.

"Well, I thought maybe you'd like to come out and walk around the grounds a bit. You've been stuck in here all week, and I thought it might be good get out of here and stretch your legs." 
Johanna pointed at the window, gesturing in the direction that Klaus had walked.

“Don't worry. He won't be back tonight. He always spends the night before any big show drinking and talking about some of his greatest performances to anyone who will listen."

Johanna wondered if she could trust this boy. Though he had been assigned to guard her all week, he'd also been nothing but kind to her each time he came with food. And although she had enjoyed the small break from her situation that her isolation provided, being confined to the small space had only served to remind her how much of a prisoner she really was. Hoping that she was right to trust him, she nodded.

"Great," he said, smiling a little more confidently.

They left the trailer. Outside, the mid-afternoon sun was bright, but the field was empty of people. It seemed that everyone was with Klaus or off making preparations for the new show tomorrow. Johanna, of course, was the main attraction, but they had left a few smaller tents for the remaining acts, with Klaus (serving as both ringleader and knifethrower), the lion tamer, an enormous bodybuilder name Bruno and his accompanying elephant, a tightrope walker, and some smaller acts, like a few clowns and a fortune teller, set up in tents and booths on both sides of her tent. Johanna also knew that Oliver was involved somehow, but she did not know what his act was. She couldn't imagine him as a clown or a main act. He was small and slight. His face was not extremely expressive or particularly handsome, though it was also not unpleasant. Instead, she thought it more that it was the kind that would make it easy for him to fade into the background and go easily unnoticed, even amongst friends. 
They walked over to the main tent. Up close, Johanna could see that workers had made incredible improvements to it. Where it had looked like it was going to crumple into a mound of dust and dirt before, it now was a clean, bright white. The trim's design had been repaired and now the deep burgundy and gold of their intertwining vines stood out against the white. The roof of the tent sloped upwards into two turrets, now with red flags waving on top. It was one of the most beautiful circus tents Johanna had ever seen.

"That seamstress and her army of stitch witches did quite a number on it, didn't they?" Oliver said, clearly awed by it himself. "I've been with this company for over a year now, and I thought for sure we were going to have to break down and get rid of this and go with one of those hideous candy-striped tents soon."

He dipped under the flap, pulling Johanna forward with him. Inside, the bleachers had all been cleared away, and, instead, only a stage was left in the center. Lights still stretched in long streams between the support beams. The only other decorations were two old, wooden chairs set up in the center of the stage, turned in to face each other. Johanna walked up to the stage and saw that the chairs were beautifully carved with all kinds of animals. Bears and elephants, lions and tigers, many kinds of birds—-hundreds of animals all marching from the bottom of the chair to the base of a giant tree that made up a great portion of the back, its branches and leaves spanning out to form the head of the chair. Johanna sat down and looked around. The space seemed to stretch out impossibly around her, and above her, the bases of turrets seemed hundreds of feet away. All the open space made her feel extremely small. Oliver sat down across from her.

"So," he started, "this is where you'll be tomorrow." 
Johanna nodded, not sure how he wanted her to react to the statement. Oliver's eyes stopped wandering around and settled on her. He bit his lower lip slightly. "I'm sorry that all of this happened to you."Johanna wished she had thought to bring something to write on. She reached out for his hand. He reached his out tentatively. She grabbed it and flipped his hand over so that his palm faced upward. His hand felt warm and sweaty as she slowly started to trace letters. He jerked his hand briefly.

"That tickles, sorry." Johanna nodded and then started over from the beginning, going one word at a time.

"I...it...it's. It's?"

Johanna nodded.

"It's...okay...we...just...have...to...deal...with...what...we...are...given... sometimes."

“I know, but this can't be what you want. You're still just a girl. I can help you, if you want. I'll get you out of here. Klaus isn't here, so we've got a good chance." His hand trembled a bit as he said this, and his eyes darted around nervously. Johanna shook her head.

No. This is fine. This is where I need to be.

He nodded, sinking back into his chair. "Far more noble than I would be."

Johanna shrugged, as if to say, "What can you do?"

Oliver shifted in his seat, and looked nervously over to the left. "It's very hard not to talk to you, you know? What am I saying, of course you know. Anyway, it's weird. It's like this need, like hunger or something. But I think that if I started, I wouldn't stop." 
You can say whatever you need. You're the first person to be this nice to me in a long time.

He just gave her hand a light squeeze in response, then, as if an idea had just struck him, grabbed her arm. "C'mon," he grinned. "I want to show you something." They rushed out of the tent and around the side to one of the smaller tents. Oliver stuck his head inside and, seeing no one, motioned her forward.

Johanna saw that they were in the lion tamer's tent. The lions looked up at them, but then laid their heads back down on the cage floor, lazily flicking their tails. Johanna approached the cage, marveling at them. She had never seen one up close before; they were beautiful.

“They're pretty tame, but I'd keep your arm out of there. Even when they're playful, they can still take a good chunk out of you," Oliver cautioned. He turned and ducked under the bleachers, rummaging through some cases that had been stored underneath. Grunting, he emerged carrying a satchel. He quickly walked over to the small ring in the center of the room and dropped the satchel on the floor. It landed with a loud, metallic clang.

"When I was a kid, I would always get so nervous before the first day of school. I was quiet and spent most of my day drawing in my notebooks, so a lot of kids just ignored me. But, for some reason, I would just get so scared. Maybe it was because I never got the chance to make a lot of friends, and so I was just scared to go back to a place where I felt lonely, even though I'd been around a lot of those people most of my life. Anyway, my mom made it this tradition that she would take me out the day before school started to do something really fun and try and calm my nerves. This one year, we 
went to a magic show, and he did the usual tricks. But there was one thing that just really amazed me."

Oliver bent down and unzipped the bag, pulling out three balls roughly the size of oranges. Johanna sat down on the bleacher nearest to the cages. One of the lions was snoring softly.

"It's weird. He sawed a girl in half, made a bird disappear from its cage, and made cards float, but the thing that most amazed me was the juggling. I knew that I had to learn to do it." As he talked, he began to toss the balls in the air. He managed to reach down into the bag and grab a few more without dropping a single one from the air, his movements quick and fluid.

"When I got out of high school, I knew right away that I wanted to be here. This group was going through my town at the time, and I showed up. Klaus didn't think he needed me, but the audience loved the show. So, I've been here ever since." He looked up at the top of the tent and tossed one ball more lightly. It landed directly on his nose, perching on the tip, perfectly balanced. He kept tossing the balls in the air.

"I can toss pretty much anything you throw at me. Plates, balls, knives, books, bats-I tried a show once where I tossed two candles without their flames going out. It's not the most exciting thing in the world, I know. But this is my gift, I guess."

Johanna realized this was the first time that she was really watching him. She'd been around him for a week and had seen him daily, but here, he stood out. He jerked his head upward and the ball returned to its arc. He bounced them off his head and feet, stood on one leg, hopped, all without losing one. Finally, he caught and dropped each one back to the satchel. 
"I better get you back. It's a big day tomorrow. But I'm glad that Klaus left tonight. You deserved a night out of that aluminum box." He zipped the bag back up and returned it to its place under the bleachers. Johanna glanced at the lions again, both sleeping now. She remembered being at the circus when she was small, clutching her mother with a mix of fear and delight when one let out a powerful roar that seemed to make the air itself tremble. Had her mother cared then, or had she only put an arm around her to show everyone else that she was a good parent, that this was what good parents did? Johanna shook her head. She didn't want to ruin the good memories of this night.

She followed Oliver back to her trailer. At the door, she reached her arms around him and gave him a hug, pulling back and mouthing a thank you.

"If you need me, l'll be out here," he said, and walked back to his normal position at the edge of the trailer. He didn't lock the door behind her.

Johanna didn't turn the lights on. She just sat down on the couch, trying hard not to think of her mother or what was to come tomorrow. She opened her mouth and tried to say random words ("meat," "angel," "Oliver," "traitor"). She had been trying this periodically over the last month without success. Just as it had before, no sound came out with her breath. Still, she attempted to force her body to make the sounds, to send words or sounds out into the increasing darkness inside her trailer. Eventually, she decided to try and sleep, dreading the coming of the dawn.

Johanna awoke to the roars of the lions, wild in their cages, and the sad trumpeting of the elephant. She heard the sound of people talking and milling about. She 
looked outside of her window and saw that a line stretched all the way through the field and up the hill back to her neighborhood. The sun was barely in the sky.

She rolled onto her back and stretched and rubbed her tired eyes. For a few minutes, she just lay there, listening to the sounds of the crowd and the animals outside, pretending that she was not the reason for all of the noise.

She heard the door open.

“Time to get your pretty self up, little girl!” Klaus called. “We already got a line a mile long of people just waiting for you, so you better be up and ready in about twenty!"

He shut the door. Johanna sat up in bed, willing her legs to move her to the bathroom, to ignore the protests of her body to simply hide away, sink into the mattress and never be seen again.

When she had cleaned herself and slipped into her dress, she stepped outside. Instantly, Oliver was at her side. He guided her along, moving through the crowd.

"Big day," he whispered. "Don't be nervous. And if you are, just think, you're the one with the gift from above. I'm the loser who learned how to juggle and still couldn't even ask a girl to borrow a pen.”

The people pointed and talked excitedly as she passed. Johanna had never felt more ridiculous in her life. At the entrance to her tent, Klaus was waiting. He had set up a table by the flap, where he would be charging admittance to see, "Johanna, the Blessed Listener." He nodded at Oliver when they approached, and took Johanna by the arm. "Remember, enthusiasm," he growled as he shoved her into the tent. She walked over to the stage and took her place in one of the chairs. She straightened her dress and 
sat up straight, looking straight ahead at the entrance. The first person came in, an older woman, approaching her nervously. Johanna smiled. 
Months passed, and yet the line of people never seemed to end. She saw people from every place conceivable. Even some of the other performers would come to see her. The lion tamer preferred the lions to people, and had a secret death wish that just once, when he put his head in the lion's mouth, the lion would finally bite down and end it. One of the clowns hated children, and was painfully unfunny. Some of the elderly would filter in, eager to confess a lifetime of transgressions, or simply to impart wisdom on someone who would listen. Johanna saw them all, no matter how they came to her. Some like penitents, some as skeptics who walked away believers, others just to gaze at her as ashow.

Waking at sunrise, Johanna would come to the tent and sit and listen, would hug and lay hands on, console as best she could until sunset. Every evening, when Klaus stood and told the people that that was it, that she would not be seeing any more people, Oliver would sneak in the tent and sit in the chair next to her, watching her with concern. As time passed, Johanna seemed to slump further and further into the chair, her head resting heavily against in the canopy of the tree behind her. Sometimes Oliver would speak, ask her if she was okay, but most of the time, he would just sit with her, holding her hand if she offered it, waiting with her until she felt ready to move back to her trailer for the evening, where he would bring her dinner and then help her to bed. 
Every day, her head felt a little bit worse, the din of countless voices bouncing through her skull. It grew increasingly harder to get out of bed, until finally Johanna began to lose all sense of time, slipping into a roaring blackness.

It took her a long time to come around, but she eventually found herself floating alone in the dark sea. The sky above was dark, making it impossible to see a thing. She could only hear the gentle waves lapping around her. Then the water began to churn and something rose up beneath her. The ocean receded around her, and she found herself standing on the stage. The audience surrounded her, watching in rapt silence. The squish of a wet footfall sounded nearby, and Johanna turned to see a horrible creature slouching toward her. Its slick, dripping skin was dark green and spotted, like a frog's, and it moved in slow, jerking motions, its legs like long sticks. It stopped near her and turned to face the applauding audience. It stretched its arms out to the side and took a slight bow. Somehow, she knew this thing was supposed to be Klaus. He turned to face her, flashing a black-gummed grin, and then he reached up, pulling a star down from the sky. Instead of a ball of gas, though, it was like crystal, with a sharp edge to each one of its five points. It still radiated heat, but it did not seem to bother him. Klaus lifted the star up to the audience, being careful to cut his finger slightly along the edge. A shocked gasp ran through the crowd. He reared his arm back, ready to throw. Johanna found she was frozen in place.

Suddenly, Oliver stepped out in front of her. Klaus narrowed his dark eyes and a soft hiss escaped his lips. Then he smirked, and launched the star at Johanna. She closed her eyes. He never missed. But nothing happened. When she opened them, Oliver was standing, his hand clutching the edge of the star. She could hear his skin sizzle with the 
heat of it, but he didn't make a sound. He held it up to the crowd. They applauded wildly. He then winked at Klaus and started tossing the star between his hands. Klaus roared, pulled another from the sky. But Oliver caught it again, and the next one, and the next. He juggled them with ease, never showing the slightest wince, even tossing some back up to the sky.

Johanna felt herself come loose from whatever held her in place. Klaus lurched toward them, and Oliver spun to face her, holding out a blackened hand, the skin bubbling with heat.

"It's time to go," he said, and her mind filled with the wailing wind again, only this time it had begun to shift.

\section{\#}

Somewhere far off, two voices were arguing.

"Get her up."

"I can't, Klaus. She's sick."

"Get her up! We're losing more people every day!"

"What will it matter if I get her to her chair? She's clearly not in any shape to listen."

“How could you let this happen to her? You're supposed to watch over her, and she ends up in some coma?"

"You're the one who pushed her this hard. I told you we needed to stop."

"Just keep trying to wake her. I'm gonna go see if Bruno can call his friend with that bear who rides the bicycle. Maybe we can get him here tomorrow."

The door slammed shut. 
"Johanna, you have to get up. You have to leave. Klaus is desperate. Please!" Nothing.

$$
\text { \# }
$$

"Little girl, I told you they would burn you up inside. You're mine now."

\#

The light got brighter, and Johanna began to stir. She opened her eyes, but the world was too bright for a moment, and she had to blink back the light until she could finally open them without pain. When she lifted her head, she noticed only an eerie silence around her. Slowly, she raised herself out of bed. Her muscles groaned in protest, but they still seemed to be in working order. She hadn't been out for too long, she supposed.

She stumbled over to the side window and peeked out through the blinds. She saw Klaus approaching. As quickly as her tender muscles would let her, she dove back into bed, covering herself and remaining completely still. She heard the door open and footsteps approached. Klaus touched her forehead with his rough fingers, pressing down on the skin.

"Fever's down. You may be coming 'round after all," he muttered. She heard him pace around for a few more moments before he trudged back out the door. There was no sound of a lock clicking into place. After waiting a few more seconds, she was up, rummaging through her things, ignoring her body's protests. She had to get out of there as quickly as she could.

Once she was sure she had enough to last her until she found somewhere safe to stay, she sneaked another look outside. Klaus was not in sight this time. The grounds 
looked completely empty, the only movement that of trash and paper drifting across the dead grass. She crept out of the door, letting it shut slowly without a sound.

"Johanna?" She jumped. Oliver. He smiled at her, but it faltered as his eyes traveled to the bag in her hand. The briefest flash of grief came over his face, but it was gone just as quickly, and he nodded in understanding. "Go," he said.

She paused, wishing she could say thank you, to convince him to come with her, but he just shook his head at her.

"Go," he repeated.

She rushed forward and hugged him quickly, hoping that he understood how thankful she was for all that he had done, and for all that he was about to endure for her. He pushed her away, urging her on. She turned and ran as fast as her body would allow her.

\section{\#}

Johanna found the widow sitting on a small knoll in the forest, not far from the dirt road that ran behind her old house. She hadn't known that she was searching for the widow until she found herself frantically running along the path, looking for the place she'd seen the widow shuffling off to long ago.

“Hello?" the widow called as Johanna approached, breathing heavily. Johanna stopped beside her, falling down in the grass. The widow reached out and touched Johanna's sweaty face.

"Johanna?"

Johanna reached over and tapped her arm once. 
"My goodness!I've heard such talk about you these past months. What's happened?"

Johanna reached over, feeling for the widow's palm, but then realized she didn't even know where to start. The widow wrapped her hand around hers.

"It's okay. Just rest."

Johanna closed her eyes. She felt her thundering heart begin to slow its pace, her muscles relaxed, and her breathing became calmer. She began to take in all that was around her. Despite the fact that autumn's end was approaching, it was an unseasonably warmday, and the sun felt hot on her face. Johanna opened her eyes and stared into it. It seemed so far away now, moving out with the changing of the season. But it still burned bright in her eyes, and she stared until it went purple. She closed her eyes again, watching it move and flash behind her eyelids.

A cold wind moved through the forest, shaking the trees and blowing through Johanna's hair. The widow gave a slight gasp.

"It'll be time to go soon," she said.

"How do I learn to live with this?" Johanna asked. It was quiet for now, barely a whisper.

"Are you not living with it already?"

"I tried to help. I listened. I heard such fantastic and terrible things, but it nearly killed me."

"Who knows how the universe works? It is constantly changing, and as it changes, so must you. Maybe, in all of its mysterious ways, the universe is simply pushing you to take a new approach." 
"I wish it would give a gentler push."

"Don't we all, when it comes to it."

The two lapsed into silence for a moment, and then the widow looked at Johanna and smiled.

"It feels like the sun is just beginning to set. Can you tell me what it looks like?"

"The sunset?"

"Yes. I used to love to watch it burn bright and orange as it sank into the horizon Sometimes I used to stare into it until my eyes would water, but I would wait until it looked purple. Then I would close my eyes and see it burning in the dark inside. But it's been a long time since then."

Johanna smiled and then looked back at the sky, contemplating what to say.

"It's still so bright, even though it's not as close. I hate that it looks like it's so far away. It makes me feel like I've lost something." She continued to watch it, slowly arching its way to the horizon line. The widow said nothing.

“It looks like it's dancing," Johanna thought aloud.

“Dancing?"

"Yes. Like it's gliding gracefully to the other side of the world."

The widow grinned at this and pointed her face to the sky, her expression open, like she was greeting an old friend. Johanna lay back down on the grass beside the widow, reveling in the silence between them. It was a silence that stretched and flourished, and neither felt the need to fill it. 
They searched for the blessed listener for many months, but she was nowhere to be found. They would wait, hoping to see news of her arrival elsewhere, and then they would go and bring her back. The tent remained in the field-no one wanted to tear it down, they would let it crumble to dust rather than give up hope that she would come back. But she had long since left, her voice now a hymn as she chased the dancing, golden light of the sun andthe roar of the ocean, with the howling wind behind her. 


\section{CURRICULUM VITAE}

NAME: Jared Andrew Beek

ADDRESS: 109 W Burnett Ave. \#1

Louisville, KY 40208

DOB: Ashland, Kentucky - October 23, 1986

EDUCATION

\& TRAINING: B.A., English

University of Kentucky

2005-2009

AWARDS: KentuckianaMetroversity Writing Competition - First Place, Graduate Fiction

2012

Sara-Jean McDowell Award - Honorable Mention

University of Louisville

2012

Creative Writing Scholarship

University of Louisville

2012

O.J. \& Ruby Wilson Scholarship for Outstanding Senior

University of Kentucky

2009

PROFESSIONAL SOCITIES: Phi Beta Kappa Honors Society

Golden Key International Honours Society

National Society of Collegiate Scholars 